論 交

\title{
熔鉱炉々壁煉瓦の侵蝕についで
}

\author{
児玉惟孝** . 宮武和海*** . 中村直人** · 加瀬正司**
}

\section{ON THE WALL EROSION OF THE BLAST FURNACE}

\author{
Koretaka Kodama, Kazumi Miyatake, Naoto Nakamura and Masashi Kase
}

\begin{abstract}
Synopsis:
Recently the life of a blast furnace has a tendency to be decided by the damage of wall bricks at the shaft. Higashida No. 5 blast furnace in Yawata Steel Works was one of these examples, too. This furnace had been operated for about seven years, and during the campaign the shaft-wall-brick had expanded and forced the charging assembly upwards about $1 \mathrm{~m}$. Consequently it was obliged to be blown out. In the dismantling work of the furnce the state of erosion and the changes of physical and chemical properties of bricks were investigated. And the structural changes of bricks were investigated with micro-photographs. The result of this investigation showed to a certatin extent the mechanism of brick degradation by alkalis, $\mathrm{CO}, \mathrm{Zn}, \mathrm{Pb}$ etc. in furnace gas penetrating through its pores, and the following counter-measures were devised.

1. Use of bricks of compact structure.

2. Shell-type construction with many cooling plates.

3. Limiting the use of raw material containing large amount of alkalis, $\mathrm{Zn}, \mathrm{Pb}$ etc.
\end{abstract}

\section{I. 緒言}

従来塎鉱炉の寿命は炉底部煉瓦の損傷によつて決定さ れる観があつたが次第に冷却法あるいは炬底カーボン煉 瓦の使用などでいちじるしく強化された結果, 最近では シヤフト部煉瓦の損耗が大きな問題となつて来た．とく にバンド式熔鉱师ではその操業中に炉体の膨脹めるいは 䍒瓦組織の崩壊現像がしばしばみられるようになつた。 八幡東田第 5 次五高恼もその一例であるが，シャフト 部の溯脹いちじるしく装入装置を約 $1 \mathrm{~m}$ 押し上げる状態 になった.この炉体の改修工事においてその侵蝕状況を 钼察し炉頂部より炬底にいたる間, 東西南北の 4 方向に おいて 22 段の略瓦積を炉内面より外周にいたる一連の 礔煉瓦の試料を採取して，化学分析，物理性質試験を おこない，さらに顕微鏡写真によつてその变質機構の把 握に努めた．さらに考察を加えて今後の操業上あるいは 如体構造上の檢討資料にせんとしたものである。

\section{II. 炉体の侵蝐状況}

東田第五高炉（第 5 次）は内容積 $647.96 \mathrm{~m}^{8}$, 公称能 力 $450 \mathrm{t} /$ day の鉄凅鉄皮式高炉でシャフト部以上がバ ンド式になつている. またシャフト部には冷却盤などの
冷却装置なく自然の空冷式になつている. 㗁和 24 年 6 月 15 日火久, 昭和 31 年 3 月 7 日吹止以約 6 年 10 力 月の操業で比校的長期間稼動したことになるがこの間総 出銑量 1,068,776 t で東田としては初めて 100 万tを 笑破した恼である.この中 $76 \%$ が製鋼銑で残り $24 \%$ が 鋳物銑の吹製となつているが，短期間毎にしばしば銑種 の切替え学行つたのは生産計画上やむを得なかつたとは 云え，炉体におよぼした影響は舤視できないむのがある。

Fig. 1 は吹入以後の炉体の膨脹状態を示したものであ るが 3 年目にはすでに邩頂サンドシールの膨脹代 550 $\mathrm{mm}$ を越え続いて灯頂装入装置を押し上げながら膨脤 してゆき 7 年目には合計 $1,300 \mathrm{~mm}$ に羊した。このため 操業中に炉頂ガス捕収管取出口の位置変更, 装入ホッパ 一の改造，シャフトバンド間に鉄板熔接して注水冷却を おこないさらにこの二次鉄皮の補強工事を実施して操業 完おこなつた。

Fig. 2 は吹降後解体時の炉体煉瓦侵䖵図であるが，さ らに試料採取位置を併せ示す.

* 昭和 32 年 10 月本会講演大会にて発表

** 八幡製鉄所製鈛部

****八幡製鉄所化工部 


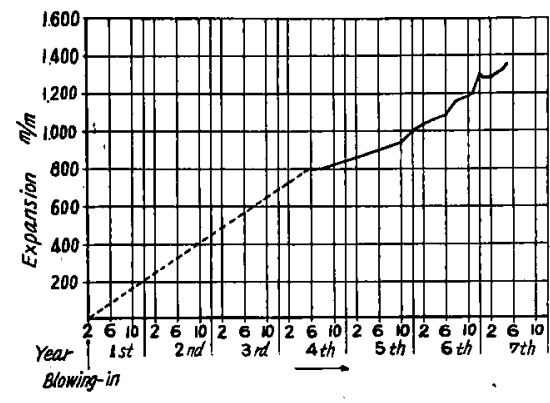

Fig. 1. Expansion of furnace body.

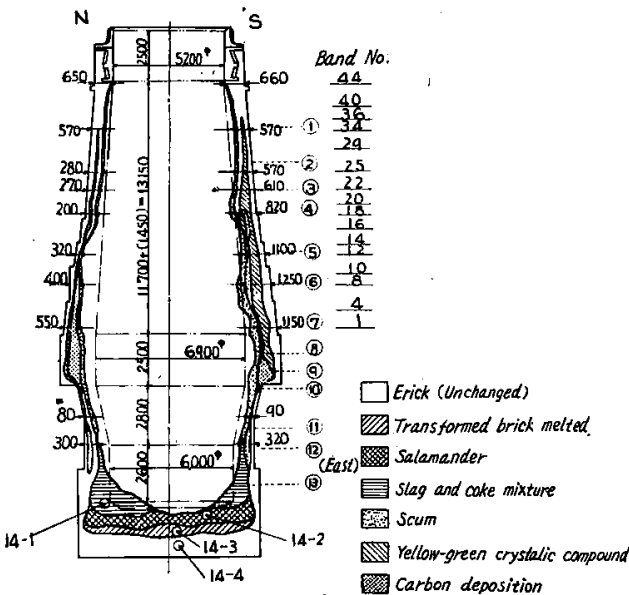

Fig. 2. The state of erosion.

Table 1 はこの操業期間における原料使用量とその割 合および炉壁侵蝕上䦗題となる $\mathrm{Zn}, \mathrm{K}_{2} \mathrm{O}, \mathrm{Na}_{2} \mathrm{O}, の$ 含 有量を示したものである。

\section{III. 炉体煉瓦の変質について}

(1) 物理化学的試験結果

Table 2 K吹入前の炉体煉瓦打よび吹入後の試料につ い厄の物理的性質を示し Table 3 に同じく試料の化学 成分を示している：主として炉体の代表的部分に分けて シャフト上部，中部，下部，朝顔，炬床出滓口部および 炉底部についてそれぞれ炉外周部より炉内側に順次に試 料を採取した位置を示している。

煉瓦はいう规も長期間高温下にさらされた為, 焼成効 果定受けていることと炉内からの flux 成分の侵入扰よ び炭素，覀鉛および鉛の析出が明らかに見られる。征つ て变質部では耐火度が低下しとくに炉腹以下でいちじる しい. 見掛比重はシャフト中段の高 $\mathrm{Zn}$ 带の上部では使 用前より大きな值宗し炉腹以下では䄸小さくなつてい る. 耐圧強度は一般に高く気孔率および荷重軟化点は低 い傾向を示している.

ZnO はシャフト中部および湯溜りに多いが炉壁では 内面よりも中央部で最大浱度を示す.シャフト中下段で は炬全周にわたつて摆状の高 Zn 変質部が形成されてい る。

$\mathrm{Pb}$ はシャフト上中段の炉壁内側よりに多く，高 $\mathrm{Zn}$ 帯の直上に接している，煉瓦に吸収されたものと粒状に なつて存在するものとあるが，湯溜部に承比較的多く存 在するのは Zn の場合とことなつている。

Kはシャフト下部，朝顔部に多いが忓壁の中央部まで 深透している。

C Nは炉腹下部より出㳯口の間にのみ存在して高K部 と一致しており $\mathrm{KCN}$ の形で存在し羽口付近で生成さ

Table 1. Zinc, $\mathrm{K}_{2} \mathrm{O}$ and $\mathrm{Na}_{2} \mathrm{O}$ contents in ore used.

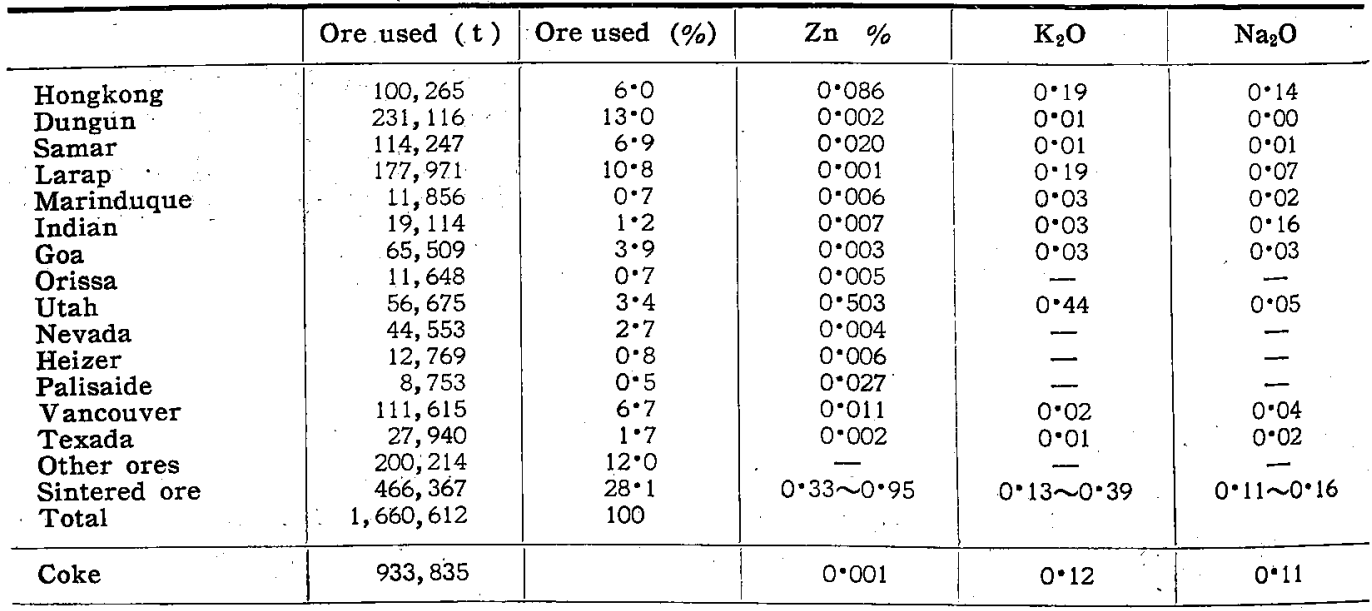


Table 2. Physical properties of fire bricks before and after blowing-in.

\begin{tabular}{|c|c|c|c|c|c|c|c|c|c|c|}
\hline \multirow{2}{*}{$\begin{array}{l}\text { Samp- } \\
\text { ling } \\
\text { No. }\end{array}$} & \multirow{2}{*}{$\begin{array}{l}\text { Place of } \\
\text { sampling }\end{array}$} & \multirow{2}{*}{$\begin{array}{l}\text { Refrac- } \\
\text { toriness } \\
(\mathrm{S} \mathrm{K})\end{array}$} & \multirow{2}{*}{$\begin{array}{l}\text { Bulk } \\
\text { density }\end{array}$} & \multirow{2}{*}{$\begin{array}{l}\text { Appa- } \\
\text { rent } \\
\text { specific } \\
\text { gravity }\end{array}$} & \multirow{2}{*}{$\begin{array}{c}\text { Apparent } \\
\text { porosity } \\
(\%)\end{array}$} & \multirow{2}{*}{$\begin{array}{l}\text { Crushing } \\
\text { strength } \\
\left(\mathrm{kg} / \mathrm{cm}^{2}\right)\end{array}$} & \multicolumn{3}{|c|}{ Softening temperature } & \multirow[b]{3}{*}{$\begin{array}{l}\text { before } \\
\text { blow-in }\end{array}$} \\
\hline & & & & & & & $\mathrm{T}_{1}\left({ }^{\circ} \mathrm{C}\right)$ & $\mathrm{T}_{2}\left({ }^{\circ} \mathrm{C}\right)$ & $\mathrm{T}_{3}\left({ }^{\circ} \mathrm{C}\right)$ & \\
\hline $\begin{array}{l}\mathrm{B}_{3} \\
\mathrm{~B}_{5} \\
\mathrm{~B}_{1}\end{array}$ & $\begin{array}{l}\text { Shaft } \\
\text { " Hearth }\end{array}$ & $\begin{array}{l}34^{\bullet} 0 \\
34 \cdot 0 \\
34^{\bullet} 0\end{array}$ & $\begin{array}{l}2 \cdot 08 \\
2 \cdot 08 \\
2 \cdot 36\end{array}$ & $\begin{array}{l}2 \cdot 77 \\
2 \cdot 72 \\
2 \cdot 74\end{array}$ & $\begin{array}{l}24 \cdot 3 \\
23 \cdot 5 \\
13 \cdot 8\end{array}$ & $\begin{array}{l}450 \\
554 \\
891\end{array}$ & $\begin{array}{l}1455 \\
1405 \\
1438\end{array}$ & $\begin{array}{l}1551 \\
1505 \\
1568\end{array}$ & $\begin{array}{l}1641 \\
1600 \\
1640\end{array}$ & \\
\hline $1 \sim 1$ & $\begin{array}{l}\text { The upper part } \\
\text { of the shaft } \\
\text { (from outside } \\
\text { to inside) }\end{array}$ & $\begin{array}{l}32 \cdot 5 \\
14 \cdot 0\end{array}$ & $\begin{array}{l}2 \cdot 11 \\
2 \cdot 47\end{array}$ & $\begin{array}{l}2 \cdot 70 \\
2 \cdot 96\end{array}$ & $\begin{array}{l}21 \cdot 6 \\
16 \cdot 6\end{array}$ & $\begin{array}{l}454 \\
511\end{array}$ & $\begin{array}{l}1400 \\
1180\end{array}$ & $\begin{array}{l}1495 \\
1385\end{array}$ & $\begin{array}{r}1595 \\
-\end{array}$ & \multirow{6}{*}{$\begin{array}{l}\text { after } \\
\text { blow-in }\end{array}$} \\
\hline $\begin{array}{r}3 \sim 1 \\
3 \\
4 \\
5\end{array}$ & $\begin{array}{l}\text { The middle part } \\
\text { of the shaft. } \\
\text { (from outside } \\
\text { to inside) }\end{array}$ & $\begin{array}{l}32 \cdot 5 \\
26 \cdot 5 \\
20 \cdot 0\end{array}$ & $\begin{array}{l}2 \cdot 10 \\
2 \cdot 83 \\
2 \cdot 69\end{array}$ & $\begin{array}{l}2 \cdot 73 \\
3 \cdot 14 \\
3 \cdot 06\end{array}$ & $\begin{array}{r}19 \cdot 7 \\
9 \cdot 6 \\
11 \cdot 7\end{array}$ & $\begin{array}{l}359 \\
988 \\
-\end{array}$ & $\begin{array}{l}1400 \\
1220 \\
-\end{array}$ & $\begin{array}{c}1505 \\
1345 \\
-\end{array}$ & $\frac{1600}{-}$ & \\
\hline $\begin{array}{r}6 \sim 1 \\
2 \\
4 \\
6 \\
7 \\
9\end{array}$ & $\begin{array}{l}\text { The lower } \\
\text { part of the } \\
\text { shaft. (from } \\
\text { outside to } \\
\text { inside) }\end{array}$ & $\begin{array}{l}33 \cdot 5 \\
16 \cdot \\
29 \cdot 5 \\
26 \cdot 0 \\
26 \cdot 0 \\
29 \cdot 0\end{array}$ & $\begin{array}{c}2 \cdot 12 \\
2 \cdot 17 \\
- \\
- \\
2 \cdot 25 \\
2 \cdot 25\end{array}$ & $\begin{array}{c}2 \cdot 73 \\
2 \cdot 73 \\
- \\
- \\
2 \cdot 67 \\
2 \cdot 58\end{array}$ & $\begin{array}{c}22 \cdot 3 \\
20 \cdot 5 \\
- \\
- \\
15 \cdot 9 \\
12 \cdot 7\end{array}$ & $\frac{298}{-}$ & $\begin{array}{c}1380 \\
1320 \\
- \\
- \\
\overline{1500}\end{array}$ & $\begin{array}{c}1485 \\
1470 \\
- \\
- \\
\overline{1600}\end{array}$ & $\begin{array}{l}1600 \\
1520 \\
- \\
- \\
-\end{array}$ & \\
\hline $\begin{array}{r}10 \sim 1 \\
2 \\
3\end{array}$ & $\begin{array}{l}\text { The bosh (from } \\
\text { outside to } \\
\text { inside). }\end{array}$ & $\frac{26 \cdot 0}{13 \cdot 5}$ & $\overline{2 \cdot 12}$ & $\overline{2 \cdot 59}$ & $\frac{18 \cdot 0}{-}$ & - & $\begin{array}{l}1240 \\
1200 \\
1100\end{array}$ & $\begin{array}{l}1280 \\
1250 \\
1175\end{array}$ & $\begin{array}{c}1320 \\
1290 \\
-\end{array}$ & \\
\hline $\begin{array}{r}13 \sim 1 \\
2 \\
3 \\
4\end{array}$ & $\begin{array}{l}\text { The hearth } \\
\text { (from outside } \\
\text { to inside) }\end{array}$ & $\frac{16 \cdot 5}{6 \cdot 5}$ & $\frac{2 \cdot 43}{-}$ & $\frac{2 \cdot 63}{\frac{-}{2 \cdot 56}}$ & $\frac{7 \cdot 5}{8 \cdot 5}$ & $\frac{920}{-}$ & $\frac{1220}{1260}$ & $\frac{1310}{-}$ & - & \\
\hline $\begin{array}{r}14 \sim 3 \\
4\end{array}$ & $\begin{array}{l}\text { The bottom } \\
\text { (from upper } \\
\text { level to lower } \\
\text { level) }\end{array}$ & $\begin{array}{l}27 \cdot 0 \\
27 \cdot 0\end{array}$ & $2 \cdot 25$ & $2 \cdot 70$ & $16 \cdot 5$ & 717 & $\begin{array}{l}1460 \\
1360\end{array}$ & $\begin{array}{l}1565 \\
1520\end{array}$ & - & \\
\hline
\end{tabular}

れていることが推察できる. Table 3 には示していない が前記筒所において $0.02 \sim 0.17 \% \mathrm{CN}$ 合有されてい る.

Cはシャフト中部以下に広く分布し炬壁内側および中 央部に多く析出沈積している.

（2）顕微鏡組織による観察

シャフト上部から炉底にいたる採取試料 68 個の中，代 表的な試料11 種を選んで偏光顕微鏡を用いて観察しだ (1) シャフト上段 (34段)

炉壁の外周部は比較的元の組織を残し mullite (3 $\left.\mathrm{Al}_{2} \mathrm{O}_{3} \cdot 2 \mathrm{SiO}_{2}\right)$ の微晶群を主体となし，しばしばよく発 達した針状結晶が見られるが肉側煉瓦は元の煉瓦組織を 保台な゙ら析出炭素によつて少し活染されている。主体 の微晶 mullite 群のところどころに glassがおきかわつ ている傾向があり zincite ( $\mathrm{ZnO}$ ) kaliophilitite $\left(\mathrm{K}_{2} \mathrm{O}\right.$. $\left.\mathrm{Al}_{2} \mathrm{O}_{3} \cdot 2 \mathrm{SiO}_{2}\right)$ および cristobalite $\left(\mathrm{SiO}_{2}\right)$ む認められ る. (Fig. 3 参照)

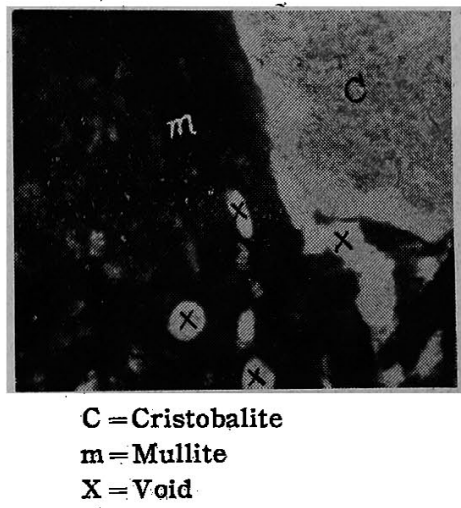

Fig. 3.

$\times 100(4 / 5)$

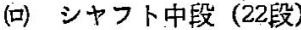

シャモット粒およびマトリックス部の区別は明らかで あるが組織はいちじるしく变化して不均一となり glass 部が増し,シャモット粒の外緣部のみに mullite 微晶が 
Table 3. Analysis of the brick and disintegrated. (\%)

\begin{tabular}{|c|c|c|c|c|c|c|c|c|c|c|c|c|}
\hline $\begin{array}{l}\text { Samp- } \\
\text { ling } \\
\text { No. }\end{array}$ & $\begin{array}{l}\text { Place of } \\
\text { sampling }\end{array}$ & $\mathrm{SiO}_{2}$ & $\mathrm{Al}_{2} \mathrm{O}_{3}$ & $\mathrm{CaO}$ & $\mathrm{MgO}$ & $\mathrm{S}$ & $\mathrm{PbO}$ & $\mathrm{ZnO}$ & T. C & T.Fe & $\mathrm{Na}_{2} \mathrm{O}$ & $\mathrm{K}_{2} \mathrm{O}$ \\
\hline $1 \sim \frac{1}{2}$ & $\begin{array}{l}\text { The upper part } \\
\text { of the shaft } \\
\text { (from outside to } \\
\text { inside) }\end{array}$ & $\begin{array}{l}48 \cdot 84 \\
34 \cdot 24\end{array}$ & $\begin{array}{l}44 \cdot 62 \\
37 \cdot 60\end{array}$ & $\begin{array}{l}2 \cdot 16 \\
2 \cdot 29\end{array}$ & $\begin{array}{l}0 \cdot 87 \\
1 \cdot 45\end{array}$ & $\begin{array}{c}\text { tr: } \\
0 \cdot 284\end{array}$ & $\begin{array}{l}\operatorname{tr} \\
3 \cdot 238\end{array}$ & $\begin{array}{l}\operatorname{tr} \\
1 \cdot 24\end{array}$ & $\begin{array}{c}\operatorname{tr} . \\
0 \cdot 15\end{array}$ & $\begin{array}{l}2 \cdot 75 \\
2 \cdot 75\end{array}$ & $\begin{array}{l}0 \cdot 40 \\
0 \cdot 40\end{array}$ & $\begin{array}{l}0 \cdot 84 \\
2 \cdot 04\end{array}$ \\
\hline $\begin{array}{r}3 \sim 1 \\
2 \\
3 \\
4 \\
5\end{array}$ & $\begin{array}{l}\text { The middle part } \\
\text { of the shaft. } \\
\text { (from outside } \\
\text { to inside) }\end{array}$ & $\begin{array}{l}49 \cdot 30 \\
41 \cdot 46 \\
25 \cdot 70 \\
34 \cdot 24 \\
17 \cdot 66\end{array}$ & $\begin{array}{r}44 \cdot 34 \\
38 \cdot 30 \\
22 \cdot 20 \\
30 \cdot 20 \\
9 \cdot 96\end{array}$ & $\begin{array}{r}1 \cdot 59 \\
0.89 \\
0.70 \\
0 \cdot 89 \\
29 \cdot 23\end{array}$ & $\begin{array}{l}0.91 \\
0.64 \\
0.58 \\
0.58 \\
3.66\end{array}$ & $\begin{array}{l}0.041 \\
0.028 \\
0.030 \\
0.550 \\
0.203\end{array}$ & $\begin{array}{l}0 \cdot 074 \\
0 \cdot 059 \\
1 \cdot 100 \\
7 \cdot 350 \\
0 \cdot 088\end{array}$ & $\begin{array}{c}0 \cdot 94 \\
13 \cdot 27 \\
37 \cdot 38 \\
5 \cdot 61 \\
\text { tr. }\end{array}$ & $\begin{array}{l}\operatorname{tr} . \\
0 \cdot 52 \\
0 \cdot 47 \\
0 \cdot 90 \\
0 \cdot 67\end{array}$ & $\begin{array}{l}2 \cdot 77 \\
1 \cdot 98 \\
1 \cdot 58 \\
1 \cdot 58 \\
3 \cdot 586\end{array}$ & $\begin{array}{l}0.40 \\
0.26 \\
0.26 \\
0.40 \\
0.40\end{array}$ & $\begin{array}{l}0 \cdot 24 \\
0 \cdot 43 \\
0 \cdot 84 \\
4 \cdot 44 \\
1 \cdot 44\end{array}$ \\
\hline $\begin{array}{r}6 \sim 1 \\
2 \\
3 \\
4 \\
5 \\
6 \\
7 \\
8 \\
9\end{array}$ & $\begin{array}{l}\text { The lower } \\
\text { part of the } \\
\text { shaft. } \\
\text { (from outside } \\
\text { to inside) }\end{array}$ & $\begin{array}{l}49 \cdot 50 \\
42 \cdot 00 \\
17 \cdot 50 \\
15 \cdot 50 \\
14 \cdot 96 \\
19 \cdot 72 \\
39 \cdot 90 \\
23 \cdot 40 \\
34 \cdot 40\end{array}$ & $\begin{array}{l}40 \cdot 40 \\
34 \cdot 84 \\
18 \cdot 30 \\
16 \cdot 10 \\
20 \cdot 40 \\
14 \cdot 80 \\
29 \cdot 50 \\
36 \cdot 10 \\
36 \cdot 54\end{array}$ & $\begin{array}{l}1 \cdot 77 \\
1 \cdot 78 \\
1 \cdot 49 \\
1 \cdot 29 \\
1 \cdot 29 \\
0 \cdot 73 \\
0 \cdot 94 \\
1 \cdot 35 \\
1 \cdot 14\end{array}$ & $\begin{array}{l}0.92 \\
1.06 \\
0.88 \\
0.88 \\
0.92 \\
0.83 \\
0.72 \\
0.98 \\
0.65\end{array}$ & $\begin{array}{l}0.030 \\
0.030 \\
0.026 \\
0.023 \\
0.022 \\
0.473 \\
1.072 \\
0.234 \\
0.137\end{array}$ & $\begin{array}{c}\text { tr. } \\
\text { tr. } \\
\text { tr. } \\
0 \cdot 294 \\
\operatorname{tr} . \\
\text { tr. } \\
20 \cdot 68 \\
0 \cdot 147 \\
\operatorname{tr} .\end{array}$ & $\begin{array}{c}\text { tr. } \\
12 \cdot 39 \\
31 \cdot 24 \\
31 \cdot 36 \\
35 \cdot 83 \\
53 \cdot 73 \\
8 \cdot 28 \\
\text { tr. } \\
\text { tr. }\end{array}$ & $\begin{array}{r}\text { tr. } \\
\text { tr. } \\
5 \cdot 35 \\
5 \cdot 35 \\
6 \cdot 82 \\
23 \cdot 32 \\
5 \cdot 89 \\
0 \cdot 82 \\
2 \cdot 45\end{array}$ & $\begin{array}{l}4 \cdot 42 \\
4 \cdot 42 \\
4 \cdot 85 \\
4 \cdot 20 \\
4 \cdot 00 \\
1 \cdot 45 \\
2 \cdot 47 \\
2 \cdot 48 \\
2 \cdot 68\end{array}$ & $\begin{array}{l}0.26 \\
0.13 \\
0.53 \\
0.13 \\
0.40 \\
0 \cdot 13 \\
0.53 \\
0.80 \\
1.60\end{array}$ & $\begin{array}{l}0 \cdot 60 \\
5 \cdot 22 \\
0 \cdot 48 \\
0 \cdot 48 \\
3 \cdot 12 \\
0 \cdot 60 \\
8 \cdot 28 \\
7 \cdot 32 \\
16 \cdot 56\end{array}$ \\
\hline $\begin{array}{r}10 \sim \begin{array}{r}1 \\
2 \\
3\end{array}\end{array}$ & $\begin{array}{l}\text { The bosh } \\
\text { (from outside } \\
\text { to inside) }\end{array}$ & $\begin{array}{l}51 \cdot 80 \\
39 \cdot 30 \\
12 \cdot 96\end{array}$ & $\begin{array}{r}35 \cdot 70 \\
26 \cdot 20 \\
5 \cdot 60\end{array}$ & $\begin{array}{l}1 \cdot 46 \\
1 \cdot 20 \\
9 \cdot 26\end{array}$ & $\begin{array}{l}0 \cdot 83 \\
0 \cdot 69 \\
2 \cdot 82\end{array}$ & $\begin{array}{l}0.032 \\
0.021 \\
0.639\end{array}$ & $\begin{array}{l}0.059 \\
0.029 \\
0.052\end{array}$ & $\begin{array}{c}1 \cdot 44 \\
11 \cdot 88 \\
\operatorname{tr} .\end{array}$ & $\begin{array}{r}0 \cdot 14 \\
4 \cdot 00 \\
31 \cdot 36\end{array}$ & $\begin{array}{l}2 \cdot 28 \\
1 \cdot 45 \\
9 \cdot 94\end{array}$ & $\begin{array}{l}0 \cdot 80 \\
1 \cdot 20 \\
1 \cdot 74\end{array}$ & $\begin{array}{l}2 \cdot 88 \\
8 \cdot 16 \\
8 \cdot 28\end{array}$ \\
\hline 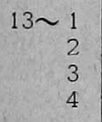 & $\begin{array}{l}\text { The hearth } \\
\text { (from outside } \\
\text { to inside) }\end{array}$ & $\begin{array}{r}42 \cdot 55 \\
7 \cdot 45 \\
0 \cdot 88 \\
12 \cdot 24\end{array}$ & $\begin{array}{r}43 \cdot 22 \\
4 \cdot 82 \\
0 \cdot 66 \\
4 \cdot 60\end{array}$ & $\begin{array}{r}6 \cdot 71 \\
8 \cdot 00 \\
0 \cdot 73 \\
16 \cdot 22\end{array}$ & $\begin{array}{l}0 \cdot 83 \\
2 \cdot 90 \\
0 \cdot 96 \\
3 \cdot 14\end{array}$ & $\begin{array}{l}0 \cdot 041 \\
0 \cdot 021 \\
0 \cdot 079 \\
0 \cdot 989\end{array}$ & $\begin{array}{l}0 \cdot 221 \\
0 \cdot 074 \\
0 \cdot 626 \\
0 \cdot 074\end{array}$ & $\begin{array}{l}0 \cdot 53 \\
6 \cdot 76 \\
54 \cdot 74 \\
\operatorname{tr}\end{array}$ & $\begin{array}{r}0 \cdot 75 \\
32 \cdot 87 \\
15 \cdot 28 \\
15 \cdot 72\end{array}$ & $\begin{array}{r}2 \cdot 07 \\
9 \cdot 21 \\
2 \cdot 07 \\
29 \cdot 50\end{array}$ & $\begin{array}{l}1 \cdot 87 \\
0.80 \\
0.93 \\
0.93\end{array}$ & $\begin{array}{l}8 \cdot 28 \\
3 \cdot 00 \\
1 \cdot 08 \\
0 \cdot 96\end{array}$ \\
\hline $\begin{array}{r}14 \sim 3 \\
4\end{array}$ & $\begin{array}{l}\text { The bottom } \\
\text { (from upper } \\
\text { level to lower } \\
\text { level) }\end{array}$ & $\begin{array}{l}46 \cdot 90 \\
48 \cdot 24\end{array}$ & $\begin{array}{l}37 \cdot 80 \\
42 \cdot 10\end{array}$ & $\begin{array}{l}1 \cdot 25 \\
0 \cdot 83\end{array}$ & $\begin{array}{l}0.85 \\
0 \cdot 75\end{array}$ & $\begin{array}{l}0.014 \\
0.036\end{array}$ & $\begin{array}{l}0.037 \\
0.074\end{array}$ & $\begin{array}{l}\text { tr. } \\
\text { tr. }\end{array}$ & $\begin{array}{c}0.35 \\
\mathbf{t r} \text {. }\end{array}$ & $\begin{array}{l}9 \cdot 32 \\
2 \cdot 69\end{array}$ & $\begin{array}{l}0.26 \\
0 \cdot 80\end{array}$ & $\begin{array}{l}3 \cdot 12 \\
3 \cdot 36\end{array}$ \\
\hline
\end{tabular}

比較的濃厚に残つている。また原組織の空隙部はほとん ど glass (多量)，zincite (稍多量) および不透明物質 (少量)で充壦され緻密な組織に変化している.さらに glass 部分には kaliophilite (少量) の晶出が見られ る. (Fig. 4 を参照)

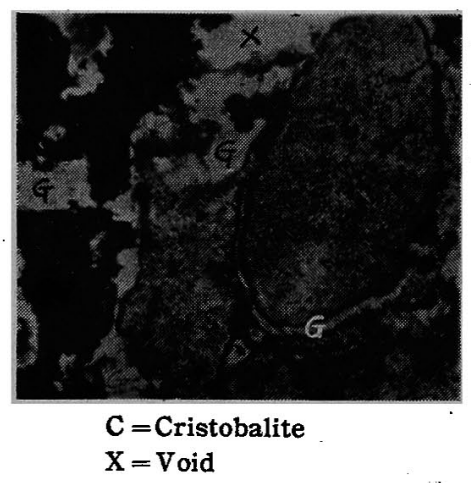

Fig. 4.

$\times 100(4 / 5)$

(y. シャフト下段（8段）

师壁中央部分は組織の約 $70 \%$ は析出炭素および不透
明物質で充璌され，透明部分は煉瓦組織の痕跡恃認めら れるがほとえど glass, kaliophilite に变化し原組織の 空隙部には $z$ incite (多量), $\beta-\mathrm{Al}_{2} \mathrm{O}_{3}$ (少量)の結晶が 出ている.

この部分の煉瓦龟裂面には多量の黄緑色 zincite 結晶 群が晶出しているがこれは真比重 5.53, igloss $0.31 \%$, $\mathrm{Al}_{2} \mathrm{O}_{3}$ 0.70\% および $\mathrm{ZnO} 96.89 \%$ であつた. (Fig. 5 Fig. 6 参照)

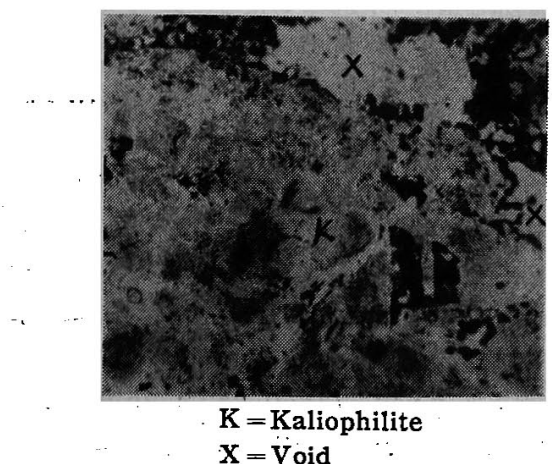

Fig. 5 . $\times 100(4 / 5)$ 


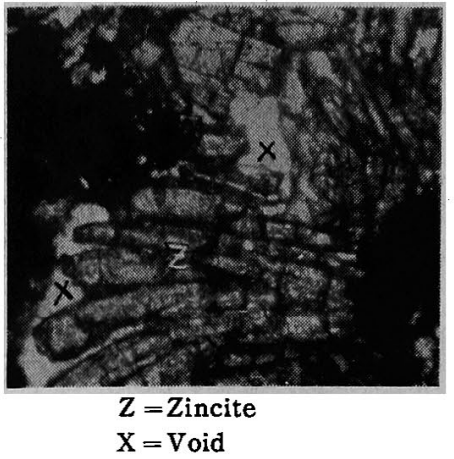

Fig. 6.

$\times 100(4 / 5)$

( )师腹部および朝顔部

妒内面部は組織の半分が沈積炭素, 含鉄化合物によつ て占められている. 透明部分は garnet属 $\left(3 \mathrm{CaO} \cdot \mathrm{Al}_{2} \mathrm{O}_{8}\right.$ ·3 $\left.\mathrm{SiO}_{2}\right)$ および少量の Anorthite $\left(\mathrm{CaO} \cdot \mathrm{Al}_{2} \mathrm{O}_{3} \cdot 2 \mathrm{SiO}_{2}\right)$ よりなり他に $\mathrm{CaCO}_{3}, \mathrm{~K}_{2} \mathrm{CO}_{3}$ などが存在している。 中央部ではその $60 \%$ が沈皘炭素その他で占められ透 明部分では原組織が残り mullite 微晶が主体でそれに 少量の残留石英が散在している. また組織の空隙部のと ころどころに zincite, kaliophilite が見られる。

(Fig. 7, Fig. 8 参照)

的炉底部

底部の上部は外観㗄瓦であるが黑鉛，金属鉄，酸化 钺などの小粒を含えでいる. 組織は全般的に mullite 微 晶捄よび針状結晶がよく発達して処々にガラス化が進ん で glass のみよりなる部分がある。

さらに下に下ると煉瓦のみで mullite 微晶が主体で 相当量の kaliophilite，と少量の酸化鉄が見られる. (Fig. 9, Fig. 10 参照)

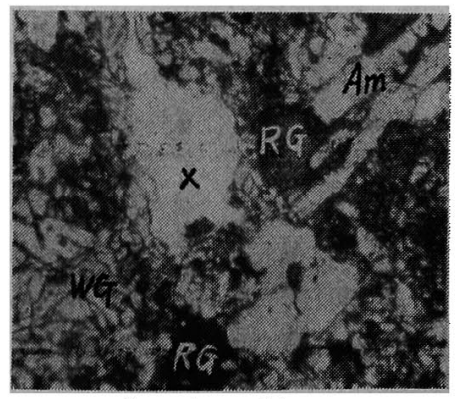

$$
\begin{aligned}
& \text { An }=\text { Anorthite } \\
& \text { RG = Garnet } \\
& \text { WG = Garnet } \\
& X=\text { Void }
\end{aligned}
$$

Fig. 7. $\times 100(4 / 5)$

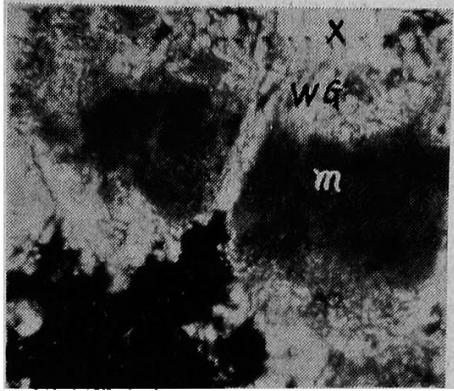

$$
\begin{aligned}
& \text { WG }=\text { Garnet } \\
& \mathrm{m}=\text { Mullite } \\
& \mathrm{X}=\text { Void }
\end{aligned}
$$

Fig. 8. $\quad \times 100(4 / 5)$

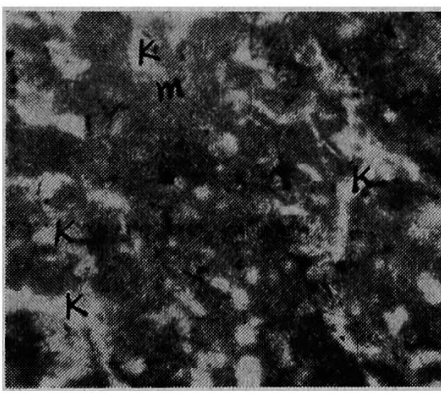

$\mathrm{K}=$ Kaliophilite $\mathrm{m}=$ Mullite

Fig. 9. $\times 100(4 / 5)$

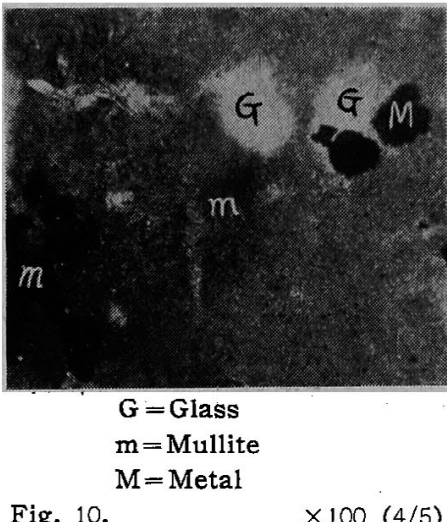

VI. 考

察

以上の結果より見るに，煉瓦組織は炉内加らの flux 成分の侵入方ほとんどない場合でも变化を来し mullite 結晶は発達し glass 量の増加が見られるが，さらにア ルカリなどの作用があると極度にガラス化が進み煉瓦組 織の熔融現象が進むことが考えられる。 
$\mathrm{C}, \mathrm{Zn}, \mathrm{Pb}$ などの析出した部分では組織の空隙部に 沈積の多いことより組織の気孔架隙部を通つてガス体が 㻏入して来たことを示すむのである.

つぎシャフト部に抢㲿る異状膨脤について考察する とその主な原因は炬壁中央部の $\mathrm{C}, \mathrm{Zn}, \mathrm{Pb}$ などの集中 的沈積現象であり, $\mathrm{CO}, \mathrm{KCl}, \mathrm{NaCl}, \mathrm{Zn}, \mathrm{Pb}$ などの気体

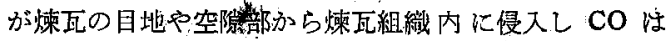
400 700 $\mathrm{C}$ ，の䉇围の部分で炭素を析出し， $\mathrm{KCl}, \mathrm{NaCl}$ などは比較的高温部 $\left(800 \sim 1400^{\circ} \mathrm{C}\right)$ で燥瓦と反応して アルカリ含有鉱物に変化しさらに Zn は $400 \sim 900^{\circ} \mathrm{C}$ の 範围で析出すると考へられる。したがつて Zn とC性同 位置任集中することになりをた酸化鉄と同様 Zn 析出の触媒作用をおこなうため一層沈皘作用か助長され るもので，この部分の煉瓦組織が極端な崩壊現象を呈し て異状膨脹をすることが理解できる。

またこのような異状膨脹が炉壁中央部で発生するため その部より内面および外周部の煉瓦皘との間に断層状の 舟裂が生じて一層大きな空隙ができですすすガズの侵 入を助長することになる.このことは高 $\mathrm{Pb}$ 部が高 $\mathrm{Zn}$ 部の直上に存在することによつても認められることで $\mathrm{Pb}, \mathrm{Zn}$ の㠜固点の順に沈積がおこなわれている.さら にこの断層状变質部の温度が煉瓦組織の变質限界温度を 示していると考えられる。

つぎに煉瓦表面はアルカリなどの作用によつて熔損が 進えでゆくが次第にアルカリ化合物の析出部が师壁中央 部へ漸次移動し遂には炭素や亜鉛などの析出部まで洛透 するようになる・したがつて炭素・重鉛などの㭛出によ る組織崩䙓がアルカリの侵入を一層容易にして勃果を助 長し合う結果となることが想像される。

しかしながら炉壁煉瓦の侵蝕が進んである限度に達す れば虾壁巾が薄くなり冷却勃果とバランスするため前述 のガス成分の析出温度あるい法反応温度範围が非常に狭 められるため炉壁侵鳋作用は急激に䌊漫になり注とえど 侵強がおこなわれなくなるものと考える。したがつて炉
壁がある原因によつて挰傷し壁门が薄くなつた場合炉壁 中央部の膨腿現象は非常飞少いか全く見られず,このた め炉周の壁巾が一様でなければ膨脹現象も一棣でなく， 㓠体法次第に傾斜して操業.上多くの困難なことが発生し てくる.第五高师が約 30 かたむいたのもこのためと考 えられる。

\section{V. 、今 後 の 対 策}

以上の考察よりシャフト上部は比較的低温で化学反応 よりる物理的摩耗分侵触の主体と考党られるが，中段以 下で注温度にとむなう化学变化がその主体と考えられ る.したがつて今後の対策として以下のことが必要であ る.

（1），使用煉瓦の性質

（1）耐火度および荷重軟化点の高いこと。

(可気孔率および通気度の低いとと。

(4)，踣化鉄の少ないとと。

$\Leftrightarrow$ 加熱による容積変化の少いこと.

(利 耐摩耗性の良好なこと。

(型状寸法の正しいこと.

（2）シャフト部冷却の効果を上げるため冷却盤を多 数使用すること.

（3）現在，当所鉄皮式熔鉱炉ではシャフト上部煉瓦 受構造を有しているが，これを使用することはかなり効 果的であると考元られる。

（4）.したがつて鉄皮式構造が望黾しい。

(5) 装六原料中のアルカリ， $\mathrm{Zn}, \mathrm{Pb}$ などの極力少 いもの，使用すべきで，とくに烍結原料である硫酸㳯の 使用泣讨十分注意する必要がある.

第五高炉の場合，二代の操業時間に $\mathrm{n}$ として1060 t 装入された。

（6）鋳物鉄，製鋼銑を短時間でしば飞ば切替えるこ とは炉壁温度の変動範囲を増加することになるので望を しくない。(昭. 33-5 月寄稿) 